\title{
Comparison Between DNA Obtained From Buccal Cells of the Upper and Lower Gutter Area
}

\author{
Fernanda NEDEL ${ }^{1}$ \\ Marcus Cristian Muniz CONDE ${ }^{1}$ \\ Isabel Oliveira de OLIVEIRA ${ }^{2}$ \\ Sandra Beatriz Chaves TARQUINIO ${ }^{3}$ \\ Flávio Fernando DEMARCO ${ }^{4}$
}

\begin{abstract}
${ }^{1}$ Dental School, Federal University of Pelotas, Pelotas, RS, Brazil
${ }^{2}$ Department of Physiology and Pharmacology, Institute of Biology, Federal University of Pelotas, Pelotas, RS, Brazil

${ }^{3}$ Department of Semiology and Clinics, Dental School, Federal University of Pelotas, Pelotas, RS, Brazil

${ }^{4}$ Department of Restorative Dentistry, Dental School, Federal University of Pelotas, Pelotas, RS, Brazil; Postgraduate

Program in Epidemiology, Federal University of Pelotas, Pelotas, RS, Brazil
\end{abstract}

\begin{abstract}
This study compared quantitatively and qualitatively the DNA extracted from buccal cells collected from the upper or lower gutter areas. Buccal cells were collected from the upper $(n=15)$ and lower gutter $(n=15)$ region from 15 volunteers using a special cytobrush $(G e n t r a)$, totaling 2 collections from each individual. DNA was extracted from the samples according to the manufacturer's instructions. The DNA obtained was qualitatively and quantitatively evaluated by 2 calibrated blind examiners using spectrophotometry and analysis of DNA bands $(0.8 \%$ agarose gel electrophoresis). Data was statistically analyzed by one-way ANOVA $(\alpha=0.05)$. Means and standard derivation (SD) for total DNA yield from the upper and lower gutter area were $12.2 \mu \mathrm{g}(12.0)$ and $9.4 \mu \mathrm{g}(8.5)$, respectively $(\mathrm{p}=0.821)$. There was higher $(\mathrm{p}<0.05)$ DNA purity for the upper gutter $(1.79 ; 0.05)$ when compared to lower gutter area $(1.66 ; 0.10)$. Regarding to the DNA quality, no differences were observed between the 2 location sites, but all samples showed similar degree of degradation. In conclusion, it would be recommendable that buccal cells for DNA extraction be collected from the upper gutter area in the attempt to increase DNA purity.
\end{abstract}

Key Words: DNA, mouth mucosa, epithelial cells, buccal cells, cytobrush.

\section{INTRODUCTION}

There are ongoing efforts to understand the genetic basis and determinants of diseases, such as cardiovascular disorders, osteoporosis, diabetes, and, especially, cancer (1-3). Fortunately, DNA is an accessible biologic material, which has adequate stability that provides information from human genome (4). The new advances in molecular biology techniques, especially polymera chain reaction (PCR), have enabled the use of a very small amount of DNA for genetics purposes (3), allowing the obtaining of DNA from more accessible sources, such as buccal cells, replacing the peripheral blood, historically the most common source of DNA for clinical and research purposes (4-7).

However, extracting DNA from buccal cells has a limitation: the yield and amount of DNA are lower than those obtained from peripheral blood $(8,9)$. Furthermore, buccal cell samples could present a large number of exogenous DNA, such as bacterial DNA, since the oral cavity is colonized by a large number of non-human cells that could be coextracted together with human genomic DNA (10). Nevertheless, the collection of buccal cell is a noninvasive method and is therefore better tolerated by adults, children and handicapped individuals $(3,7,9,11,12)$. In a recent study with a Danish Nurse Cohort, when each group of nurses was requested to deliver a blood sample, a buccal cell sample collected by swabs, FTA cards or saliva, the response rates were respectively $31,80,76$ and $72 \%$ (1), demonstrating the difficulty to obtain blood samples. In addition, the collection of buccal cells is a method that does not require

Correspondence: Prof. Dr. Flávio Fernando Demarco, Faculdade de Odontologia, Universidade Federal de Pelotas, Rua Gonçalves Chaves, 457, 96015-560 Pelotas, RS, Brasil. Tel: +55-53-3225-6741. Fax:+55-53-3225-5581. e-mail: flavio.demarco@pq.cnpq.br 
a trained medical assistance, participants could selfcollect the samples and mail them to the research center avoiding traveling expenses, which can reduce the costs for epidemiological studies. Also, the technique is inexpensive when compared to other methods $(3,7,9,11,12)$.

Two different procedures are used to collect buccal cell samples: the dry method that uses cytobrushes, buccal swabs, or other implements for scraping the oral mucosa; and the wet procedure that consists in swishing liquid in the mouth and spiting it into a collecting cup $(2,3,13)$. The majority of studies that involve buccal cell collection and subsequent DNA extraction use cytobrushes or mouthwash rinses (12).

Collection with cytobrushes involves rubbing a brush onto the mucosa for a certain time, the cheek being the area of choice in most studies. Saftlas et al. (12) proposed, as an alternative method, the gutter area (region located between the upper gum line and the mucosa of the upper lip and cheek) for buccal cell collection, due to the maximized surface area contact between the cytobrush and mucosa. In a previous study, Nedel et al. (3) collected buccal cells from gutter, which proved to be a good source to obtain DNA. However, the authors emphasized that the method should be better investigated to improve the quality and quantity of DNA obtained. To date, there are no scientific data indicating whether gutter sample collection could influence the DNA obtaining results. Therefore, the purpose of this study was to compare quantitatively and qualitatively the DNA extracted from buccal cells collected from the upper and lower gutter area.

\section{MATERIAL AND METHODS}

The research protocol was approved by the Research Ethics Committee of the Federal University of Pelotas, Brazil. Fifteen adult voluntaries $(n=15)$ aged 18-30 years were selected and signed a written informed consent form to be enrolled in the study. Each participant provided 2 collection samples: one from the right upper and one from the right lower gutter area.

Samples were collected using disposable special cytological brushes (Purgene DNA Buccal Cell Kit; Gentra Systems, Inc., Minneapolis, MN, USA) and the volunteers were instructed to brush and twirl each cytobrush for $15 \mathrm{~s}$ over the gutter region. After collection, the cytobrushes were immediately introduced in a microfuge tube containing cell lysis solution. All samples were then processed according to the manufacturer's instructions. After processing each sample, $20 \mu \mathrm{L}$ of solution was obtained. From this amount, $10 \mu \mathrm{L}$ were placed in a tube containing $90 \mu \mathrm{L}$ of Milli-Q water, the concentration (determined at the absorbance of $260 \mathrm{~nm}$ ) and purity (determined by the absorbance ratio $260 / 280$ $\mathrm{nm}$ ) of DNA was measured using a spectrophotometer (Eppendorf Biophotometer, Hamburg, Germany). The data obtained from total DNA yield measured at $260 \mathrm{~nm}$ and the absorbance $260 / 280 \mathrm{~nm}$ ratio were statistically analyzed by one-way ANOVA at 5\% significance level.

In order to ascertain the presence of high molecular weight DNA in the sample, the remaining $10 \mu \mathrm{L}$ of each sample was used to run a $0.8 \%$ agarose gel electrophoresis at $2 \mathrm{~V} / \mathrm{cm}$ and were stained with ethidium bromide. The DNA degradation was observed by fragmentation of the samples compared against a known molecular weight marker. The visible bands were examined by 2 calibrated examiners, which were not enrolled in the study.

\section{RESULTS}

Means and standard derivation (SD) for total DNA yields measured at $260 \mathrm{~nm}$ from the upper and lower gutter area were $12.2 \mu \mathrm{g}(12.0)$ and $9.4 \mu \mathrm{g}(8.5)$, respectively. Although numerically different, the statistical analysis did not show significant differences between upper and lower gutter area $(\mathrm{p}=0.821)$.

The estimation of DNA purity was measured using the absorbance $260 / 280 \mathrm{~nm}$ ratio, the values for the upper and lower gutter areas were $1.79(0.05)$ and $1.66(0.10)$, with a statistically significant difference between them $(p<0.05)$. Regarding the quality of the DNA extracted, no differences in band patterns were observed in the agarose gel, but all samples showed some degree of degradation (Fig. 1).

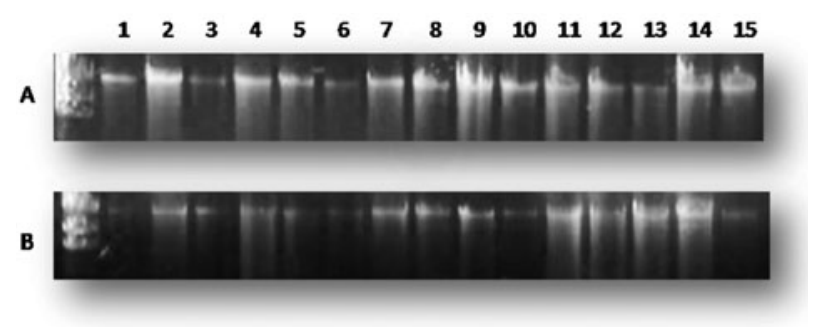

Figure 1. Quality ofDNA evaluated by agarose gel electrophoresis. A = Samples collected from the upper gutter; B = Samples collected from the lower gutter area. 


\section{DISCUSSION}

Buccal cells have been used as a source of DNA in several large epidemiological studies as the primary sample or supplementary to blood samples (14). Despite the fact that buccal cells samples usually provide a smaller amount of DNA than blood sample, recent development methods of genotyping and genomic sequencing use very small amounts of DNA, making the collection of buccal cells a valuable source of genetic material with high quality (3). However, the goal is always to obtain the maximum of DNA with the best quality possible. Therefore assessing the better location in the oral cavity for collection of buccal cell in an attempt to increase total DNA yield, is an important issue.

When cytobrush is the selected method for collecting buccal cells, the cheek mucosa is usually the chosen area of the oral cavity. However, Saftlas et al. (12) proposed the use of the gutter area as an alternative method in order to maximize the surface area contact between the cytobrush and mucosa. Those authors found that the gutter area of adult females provided significantly larger amount of DNA $(7.5 \mu \mathrm{g})$ compared to method of brushing the inner cheeks $(3.8 \mu \mathrm{g})$. Nevertheless, in a recent study, DNA yield from the gutter area $(3.0-4.1 \mu \mathrm{g})(3)$ was similar from those obtained from the cheek region $(3.5 \mu \mathrm{g})$ in another study (15).

In the present work, the total yield of DNA provided by buccal cell collected from the gutter region (upper gutter $=12.2 \mu \mathrm{g}$ and lower gutter $=9.4 \mu \mathrm{g}$ ) was higher than those presented by previous studies $(3,12)$. Witsø et al. (16) also showed high values for DNA yield ( $28.3 \mu \mathrm{g}$ per mouth brush), relating these data with impurities presented in the samples (absorbance 260/280 nm ratio=1.22). Although impurities was also found in the samples of the present study, the mean ratio was higher (1.79 and 1.66 for the upper and lower gutter) to those found by Witsø et al. (16). This suggests that the high values for DNA yield were not attributed to impurities because absorbance 260/280 ratio values of 1.7-2.0 have been reported to predict "clean DNA" (17).

The higher values obtained in the present study are more likely to the wide variation between individuals in desquamation of oral mucosa (13) and individual aspects such as the force applied during collection $(3,15)$. Also, it is well described that buccal samples are contaminated with bacterial DNA. García-Closas et al. (11) determined by hybridization that cytobrush methods contain a mix- ture of human and nonhuman DNA and that only $11 \%$ of total DNA found in cytobrush is from human origin. While in that study (11) the samples were processed 1 to 4 days after collection, and subjects were asked to brush their teeth $10-15$ min prior to collection, in the present investigation study, the extraction process initiated immediately after collection, so that contamination could be minimized, because bacterial contamination primarily depends on the way samples are stored after collection (1). However, no method to control contamination was used in subjects prior to collection in the present study, what could increase non-human DNA in the samples, increasing the total DNA yield. Another issue that could influence DNA yield is the different DNA extraction methods, such as phenol-chloroform, Purgene DNA Buccal Cell Kit or others (15).

Although different collection areas of the mouth have been evaluated to increase the DNA yield (11-13), until now, to the best of our knowledge, no study has compared the DNA collected from upper and lower gutter area in the same subject. In this study, numeric differences were observed when comparing DNA yield of both location, but these differences were not statistically significant. Yet, it is important to highlight that the 2.8 $\mu \mathrm{g}$ difference between the upper and lower gutter area could be attributed to the deposition of more saliva in the lower gutter due to the gravity, which may contribute to the continually washing out of buccal cells, as well as bacterial cells. Accumulation of saliva could also decrease the attrition between the cheek mucosa and the gum line what provides less desquamation, decreasing cell collection and DNA extraction (18).

Another factor that could influence DNA yield is the proximity between the cheek and the gum line that seems to be higher in the upper then the lower gutter; which could contribute to mucosa continuously friction allowing the desquamation of a higher quantity of cells. Moreover, significant differences observed between the upper (1.79) and lower gutter (1.66) regarding impurities could be more likely related to the increase of DNA provided by upper gutter than from higher protein levels in the sample, once the method of extraction was the same and samples were manipulated in the same form.

The qualitative evaluation was based on the $0.8 \%$ agarose gel observation (Fig. 1), where no significant difference was observed between the tested group. With the qualitative analysis was possible to detect some degradation of the samples. Acoordingt to King 
et al. (13), DNA from cytobrush suffers a degradation process, observed by agarose gel, what could justify the sufficient DNA fragments for short and intermediate amplification primers (up to $1.1 \mathrm{~kb}$ ), with poor results for longer gene fragments (i.e., $7.8 \mathrm{~kb}$ ) in measurement by PCR amplification of DNA collected from cytobrush.

In conclusion, the findings of the present study suggest that it is recommendable that buccal cells for DNA extraction be collected from the upper gutter area in the attempt to increase purity of DNA samples.

\section{RESUMO}

O objetivo do presente estudo foi comparar quantitativamente e qualitativamente o DNA extraído de células epiteliais bucais coletadas do fundo de sulco superior e inferior. Foram coletadas células bucais do fundo de sulco superior $(\mathrm{n}=15)$ e inferior $(\mathrm{n}=15)$ de 15 voluntários utilizando escovas citológicas especiais (Gentra), totalizando 2 coletas por voluntário. Após a coleta o DNA foi extraído conforme o protocolo indicado pelo fabricante (Puregene DNA Buccal Cell Kit; Gentra Systems, Inc.). O DNA obtido foi avaliado quantitativamente e qualitativamente por dois examinadores calibrados cegos utilizando espectrofotometria e análise das bandas de DNA (gel de agarose $0,8 \%$, por eletroforese). Os dados foram submetidos a ANOVA a um critério, com $p<0,05$. As médias e desvio padrão (DP) para o rendimento total de DNA do fundo de sulco superior e inferior foram respectivamente $12,2 \mu \mathrm{g}(12,0)$ e $9,4 \mu \mathrm{g}(8,5)(\mathrm{p}=0,821)$. Houve maior $(\mathrm{p}<0,05)$ pureza de DNA no fundo de sulco superior $(1,79 ; 0,05)$ quando comparado com o fundo de sulco inferior $(1,66 ; 0,10)$. Quanto à qualidade do DNA, não foi observado diferenças entre os dois locais testados, no entanto todas as amostras mostraram níveis de degradação semelhantes. Em conclusão seria recomendável coletar células bucais, para extração de DNA, do fundo de sulco superior na tentativa de aumentar a pureza do DNA.

\section{REFERENCES}

1. Hansen TV, Simonsen MK, Nielsen FC, Hundrup YA. Collection of blood, saliva, and buccal cell samples in a pilot study on the Danish nurse cohort: comparison of the response rate and quality of genomic DNA. Cancer Epidemiol Biomarkers Prev 2007; 16:2072-2076.

2. Saab YB, Kabbara W, Chbib C, Gard PR. Buccal cell DNA extraction: yield, purity, and cost: a comparison of two methods. Genet Test 2007;11:413-416.

3. Nedel F, André de A, de Oliveira IO, Tarquinio SB, Demarco FF. Buccal cells submitted to three different storage conditions before DNA extraction. J Appl Oral Sci 2009;17:113-115.
4. Lema C, Kohl-White K, Lewis LR, Dao DD. Optimized pH method for DNA elution from buccal cells collected in Whatman FTA cards. Genet Test 2006;10:126-130.

5. Richards B, Skoletsky J, Shuber AP, Balfour R, Stern RC, Dorkin HL, et al. Multiplex PCR amplification from the CFTR gene using DNA prepared from buccal brushes/ swabs. Hum Mol Genet 1993;2:159-163.

6. Lum A, Le Marchand L. A simple mouthwash method for obtaining genomic DNA in molecular epidemiological studies. Cancer Epidemiol Biomarkers Prev 1998;7:719-724.

7. Etter JF, Neidhart E, Bertrand S, Malafosse A, Bertrand D. Collecting saliva by mail for genetic and cotinine analyses in participants recruited through the Internet. Eur J Epidemiol 2005;20:833-838.

8. Walker AH, Najarian D, White DL, Jaffe JF, Kanetsky PA, Rebbeck TR. Collection of genomic DNA by buccal swabs for polymerase chain reaction-based biomarker assays. Environ Health Perspect 1999;107:517-520.

9. Beckett SM, Laughton SJ, Pozza LD, McCowage GB, Marshall G, Cohn RJ, et al.. Buccal swabs and treated cards: methodological considerations for molecular epidemiologic studies examining pediatric populations. Am J Epidemiol 2008;167:1260-1267.

10. Herráez DL, Stoneking M. High fractions of exogenous DNA in human buccal samples reduce the quality of large-scale genotyping. Anal Biochem 2008;383:329-331.

11. García-Closas M, Egan KM, Abruzzo J, Newcomb PA, Titus-Ernstoff L, Franklin T. et al.. Collection of genomic DNA from adults in epidemiological studies by buccal cytobrush and mouthwash. Cancer Epidemiol Biomarkers Prev 2001;10:687-696.

12. Saftlas AF, Waldschmidt M, Logsden-Sackett N, Triche E, Field E. Optimizing buccal cell DNA yields in mothers and infants for human leukocyte antigen genotyping. Am J Epidemiol 2004;160:7784.

13. King IB, Satia-Abouta J, Thornquist MD, Bigler J, Patterson RE, Kristal AR, et al.. Buccal cell DNA yield, quality, and collection costs: comparison of methods for large-scale studies. Cancer Epidemiol Biomarkers Prev 2002;11:1511.

14. Steinberg K, Beck J, Nickerson D, Garcia-Closas M, Gallagher M, Caggana M, et al.. DNA banking for epidemiologic studies: a review of current practices. Epidemiology 2002;13:246-254.

15. Mulot C, Stücker I, Clavel J, Beaune P, Loriot MA. Collection of human genomic DNA from buccal cells for genetics studies: comparison between cytobrush, mouthwash, and treated card. J Biomed Biotechnol 2005;2005:291-296.

16. Witsø E, Stene LC, Paltiel L, Joner G, Rønningen KS. DNA extraction and HLA genotyping using mailed mouth brushes from children. Pediatr Diabetes 2002;3:89-94.

17. Ahn SJ, Costa J, Emanuel JR. PicoGreen quantitation of DNA: effective evaluation of samples pre- or post-PCR. Nucleic Acids Res 1996;24:2623-2625.

18. Squier CA, Kremer MJ. Biology of oral mucosa and esophagus. J Natl Cancer Inst Monogr 2001;29:7-15.

Accepted August 29, 2009 